\title{
Postnatal liver growth and regeneration are independent of $c-m y c$ in a mouse model of conditional hepatic c-myc deletion
}

\author{
Jennifer A Sanders ${ }^{1 *}$, Christoph Schorl ${ }^{2,3}$, Ajay Patel ${ }^{4}$, John M Sedivy ${ }^{2,3}$ and Philip A Gruppuso ${ }^{1,2}$
}

\begin{abstract}
Background: The transcription factor c-myc regulates genes involved in hepatocyte growth, proliferation, metabolism, and differentiation. It has also been assigned roles in liver development and regeneration. In previous studies, we made the unexpected observation that c-Myc protein levels were similar in proliferating fetal liver and quiescent adult liver with c-Myc displaying nucleolar localization in the latter. In order to investigate the functional role of c-Myc in adult liver, we have developed a hepatocyte-specific c-myc knockout mouse, c-myct/flf; $A l b-C r e$.

Results: Liver weight to body weight ratios were similar in control and c-myc deficient mice. Liver architecture was unaffected. Conditional c-myc deletion did not result in compensatory induction of other myc family members or in c-Myc's binding partner Max. Floxed c-myc did have a negative effect on Alb-Cre expression at 4 weeks of age. To explore this relationship further, we used the Rosa26 reporter line to assay Cre activity in the c-myc floxed mice. No significant difference in Alb-Cre activity was found between control and c-myct/ffl mice. c-myc deficient mice were studied in a nonproliferative model of liver growth, fasting for $48 \mathrm{hr}$ followed by a $24 \mathrm{hr}$ refeeding period. Fasting resulted in a decrease in liver mass and liver protein, both of which recovered upon $24 \mathrm{~h}$ of refeeding in the $c-m y c^{f / f f l} ; A / b-C r e$ animals. There was also no effect of reducing $c-m y c$ on recovery of liver mass following $2 / 3$ partial hepatectomy.
\end{abstract}

Conclusions: c-Myc appears to be dispensable for normal liver growth during the postnatal period, restoration of liver mass following partial hepatectomy and recovery from fasting.

\section{Background}

The Myc family includes three closely related genes, $c$ $m y c, L-m y c$, and $N-m y c$, which have been shown to have similar biological activities. The three Myc proteins are basic helix-loop-helix leucine zipper transcription factors that heterodimerize with a binding partner, Max, to bind DNA and either activate or repress the transcription of a large set of target genes [1-3]. An additional member of the family, $B-m y c$, encodes a protein that is homologous to the N-terminal domain of c-Myc, but its function remains largely unknown [4]. c-Myc has been shown to regulate genes involved in ribosomal biogenesis, protein translation and the transition from the $\mathrm{G0} /$ G1 to S-phase of the cell cycle suggesting that c-Myc

\footnotetext{
* Correspondence: Jennifer_Sanders@brown.edu

'Department of Pediatrics, Rhode Island Hospital and Brown University, Providence, RI 02903, USA

Full list of author information is available at the end of the article
}

has a functional role in the coordination of cellular growth and proliferation. The expression of $c-m y c$ is, in general, tightly regulated. Proliferating cells contain high levels of this protein, while the level of c-Myc is significantly decreased as cells growth arrest and differentiate [3]. Dysregulated expression of $c-m y c$ is associated with the development of many tumors in rodents and humans, including hepatocellular carcinoma [5-7].

c-Myc has been implicated as a regulator of hepatocyte proliferation, growth and metabolism [8,9]. During the process of liver regeneration, quiescent hepatocytes synchronously enter the cell cycle and undergo one, two or more rounds of replication to restore liver mass [10]. Considered an immediate early gene, $c-m y c$ expression is induced within 30 minutes following partial hepatectomy and has been suggested to be a key factor in the transcriptional response leading to the progression of hepatocytes from G0/G1 to S phase [11]. Transient
C Biomed Central

C 2012 Sanders et al; licensee BioMed Central Ltd. This is an Open Access article distributed under the terms of the Creative Commons Attribution License (http://creativecommons.org/licenses/by/2.0), which permits unrestricted use, distribution, and reproduction in any medium, provided the original work is properly cited. 
overexpression of c-Myc in mouse liver results in hepatocyte enlargement and induction of ribosomal and nucleolar genes [12]. Other studies involving $c$-myc transgenic mice have shown that overexpression of $\mathrm{c}$ Myc in the liver induces hepatic glucose uptake and utilization and can inhibit gluconeogenesis [13,14]. While these studies support a role for c-Myc in hepatocyte growth, ribosomal biogenesis and metabolism, they do not address whether $\mathrm{c}-\mathrm{Myc}$ is required or whether the effects on these processes were due to superphysiological levels of c-Myc.

Previous studies from our laboratory on the regulation of c-Myc during rat liver development revealed several novel findings. First, in contrast to many other organ systems and cell types, rapidly proliferating fetal and quiescent adult liver contained similar levels of c-Myc protein. In adult hepatocytes, $\mathrm{c}-\mathrm{Myc}$ was localized to the nucleolus, while fetal hepatocytes displayed diffuse nuclear localization. In addition, c-Myc translocated out of the nucleolus in response to a partial hepatectomy $[15,16]$. These data led us to hypothesize that hepatic cMyc may play a functional role in liver other than its well established role in hepatocyte proliferation. In order to examine the function of $\mathrm{c}-\mathrm{Myc}$ in adult liver, we mated mice in which the $c-m y c$ locus was floxed to mice expressing Cre recombinase under the control of the albumin promoter. The present paper describes the characterization of these mice.

\section{Methods}

Animals

$c-m y c^{f l / f l}$ mice were gifts of I. Moreno de Alboran [17]. $A l b$-Cre and ROSA26 mice were obtained from Jackson Laboratories (Bar Harbor, ME $[18,19]$ ). All mice were C57BL/6 strain housed in a pathogen-free facility and maintained on a $12 \mathrm{hr}$ light/dark cycle. $c-m y c^{f l / f l}$ mice were mated to $A l b$-Cre mice to achieve mice that carried a floxed $c-m y c$ allele and $A l b$-Cre. Littermates were bred to obtain $c-m y c^{f l / f l} ; A l b-\mathrm{Cre}^{+}$mice and the control mice $\left(c-m y c^{f l / f l} ; A l b-\mathrm{Cre}^{-/-}, c-m y c^{+/+} ; A l b-\mathrm{Cre}^{+}\right)$. Progeny were mated to obtain $c-m y c^{f l / f l} ; A l b-\mathrm{Cre}^{+/+}$mice and the control $c-m y c^{+/+} ; A l b-\mathrm{Cre}^{+/+}$mice. Breeding pairs that produced litters consisting exclusively of $\mathrm{Cre}^{+}$pups for at least 5 successive matings were considered $\mathrm{Cre}^{+/+} . c_{-}$ $m y c^{f l / f l} ; A l b-\mathrm{Cre}^{+/+}$and the control $c-m y c^{+/+} ; A l b-\mathrm{Cre}^{+/+}$ lines were established from these pairs. Pups from both sexes were used for all analyses except 2/3 partial hepatectomy. Blood glucose concentrations were determined using a YSI 2300 STAT plus glucose and lactate analyzer (YSI Life Sciences; Yellow Springs, OH).

For fasting and refeeding experiments, eight week old male and female $c-m y c^{f l f l}$ and $c-m y c^{+/+} ; A l b$-Cre expressing mice were fed standard rodent chow ad libitum (control) or fasted for $48 \mathrm{hr}$. Where noted, standard rodent chow was replaced in the cage covers and animals were allowed to feed ad libitum for $24 \mathrm{hr}$ (refed). Water was freely available to all mice. Eight to ten week old male $c-m y c^{f l f l}$ and $c-m y c^{+/+} A l b$-Cre expressing mice were anesthetized using isoflurane and subjected to $2 / 3$ partial hepatectomy as described by Higgins and Anderson [20]. All mice were killed by exsanguination under isoflurane anesthesia. Carcass and liver weights were recorded. The liver was divided and fixed in $10 \%$ neutral buffered formalin or flash frozen in liquid nitrogen before being stored at $-70^{\circ} \mathrm{C}$.

To assess Cre activity, female $c-m y c^{f l / f l} ; A l b-\mathrm{Cre}^{+/+}$and $c-\mathrm{myc}^{+/+} ; \mathrm{Alb}-\mathrm{Cre}^{+/+}$were crossed with male ROSA26 mice. Mice were further mated to obtain the following genotypes used for study, $c-m y c^{f l / f l} ; A l b-\mathrm{Cre}^{+}$;ROSA $26^{+}$ and $c-m y c^{+/+} ; A l b-\mathrm{Cre}^{+} ; \mathrm{ROSA} 26^{+}$. Mice were genotyped using PCR analysis of tail genomic DNA according to published protocols for $c$-myc [21], Alb-Cre transgene [22] and the ROSA26 alleles http://jaxmice.jax.org/protocolsdb/f?p=116:1:3259541732707236::NO:::.

All experiments on mice were performed in accordance with the guidelines of the National Institutes of Health and the Rhode Island Hospital Institutional Animal Care and Use Committee.

\section{DNA Isolation and qPCR}

DNA was isolated from triplicate frozen livers obtained from $c-m y c^{f l / f l} ; A l b-\mathrm{Cre}^{-/-}, c-m y c^{f l / f l} ; A l b-\mathrm{Cre}^{ \pm}$and $c-m y c^{f l l}$ ${ }^{f l} ; A l b-\mathrm{Cre}^{+/+}$mice at 4,8 , and 10 weeks of age using the DNeasy kit (Qiagen; Valencia, CA). qPCR reactions were performed in triplicate using $25 \mathrm{ng}$ of DNA, $23 \mu \mathrm{l}$ SYBR green reaction mix, and the 7500 Real-Time PCR system (Applied Biosystems; Foster City, CA). In order to detect the deletion of the $c-m y c^{f l}$ allele, primers were designed upstream of the 5' lox $\mathrm{P}$ site (primers $\mathrm{X}$ and $\mathrm{Y}$ ) and on either side of the 3' lox $\mathrm{P}$ site (NB). The primer sequences are as follows: primer $\mathrm{X}, 5^{\prime}$-CCTC GCGCCCCTGAA-3'; primer Y, 5'-AACCGCTCAGAT CACGACTCA-3'; primer N, 5'-TCCAAACCAGA AACTGAAACATGT-3'; primer B, 5'-ACAATGGGGTC ATTTAGGAC-3'. The relative abundance of the $c-m y c^{f l}$ allele was calculated by the comparative $C_{T}$ method using the product generated by primers $\mathrm{X}$ and $\mathrm{Y}$ as the reference. $c-m y c$ deletion during liver regeneration was assessed by calculating the $\mathrm{ddCt}(\mathrm{dCt}$ in liver removed at the time of hepatectomy- minus the $\mathrm{dCt}$ in regenerating liver from the same animal) for triplicate mice.

\section{RNase protection assay}

Total RNA was isolated from triplicate frozen livers obtained from 8 and 10 week old $c-m y c^{+/+}$and $c-m y c^{f l / f l}$ Alb-Cre expressing mice as previously described [15]. RNase protection assays were performed using the mMyc multiprobe template with yeast tRNA as a 
negative control (BD Biosciences; San Diego, CA). L32 was used as an internal control to normalize expression data. Quantification of bands was performed by digital analysis using LabWorks software (UVP; Upland, CA).

\section{RT-qPCR}

Total RNA was isolated from frozen livers obtained from 4, 8, and 10 week old control $\left(c-m y c^{f l f f l} ; A l b-\mathrm{Cre}^{-/-}\right.$ and $\left.c-m y c^{+/+} ; A l b-C r e\right)$ and $c-m y c^{f l / f l} ; A l b-C r e$ mice using the RiboPure Kit (Ambion; Foster City, CA). RNA was cleaned using the RNeasy kit (Qiagen) and cDNA synthesized using random hexamers and the TaqMan Reverse Transcription kit (Applied Biosystems). Primer sequences used for amplification of cre were 5'-CGATG CAACGAGTGATGAGG-3' for the sense primer and 5'GGCAAACGGACAGAAGCATT-3' for the antisense primer. Mouse $c-m y c$ primers were obtained from SABiosciences (Frederick, MD). The internal standard GAPDH was amplified using the following primer sequences, 5'-TCCAGTATGACTCCACTCACGG-3' and 5'-TCGCTCCTGGAAGATGGTG-3'. The relative abundance of $c r e$ and $c-m y c$ was calculated by the comparative CT method using GAPDH as the reference.

\section{Histology and image analysis}

Liver was fixed in 10\% neutral buffered formalin, paraffin embedded, and stained with hemotoxylin and eosin. Immunohistochemistry was performed for Ki-67 using the indirect immuneperoxidase technique. Briefly, sections were deparaffinized and microwaved in $100 \mathrm{mM}$ sodium citrate buffer, $\mathrm{pH} 6.0$ for 20 minutes, followed by incubation in anti-Ki-67 antibody (Abcam, Cambridge, MA) overnight at $4^{\circ} \mathrm{C}$. Slides were scanned with an Aperio Scanscope CS (Aperio Technologies, Inc., Vista, CA). Ki-67 positive cells in ten $20 \times$ fields were counted. For Lac-Z staining, liver cryosections $(10 \mu \mathrm{m})$ were fixed in phosphate buffered saline, $\mathrm{pH} 7.3$ (140 $\mathrm{mM} \mathrm{NaCl} ; 2.7 \mathrm{mM} \mathrm{KCl} ; 8.1 \mathrm{mM} \mathrm{Na} 2 \mathrm{HPO}_{4} ; 1.5 \mathrm{mM}$ $\mathrm{KH}_{2} \mathrm{PO}_{4}$ ) containing $0.2 \%$ gluteraldehyde, $10 \mathrm{mM}$ EGTA, and $2 \mathrm{mM} \mathrm{MgCl}_{2}$. Sections were washed three times with phosphate buffered saline containing 0.05 mM EGTA, $2 \mathrm{mM} \mathrm{MgCl}_{2}, 0.12 \mathrm{mM} \mathrm{Na}$ deoxycolate, and $0.02 \%$ Nonidet $\mathrm{P}-40$ and incubated overnight in the same solution containing $10 \mathrm{mM} \mathrm{K}_{3} \mathrm{Fe}(\mathrm{CN})_{6}, 10 \mathrm{mM}$ $\mathrm{K}_{4} \mathrm{Fe}(\mathrm{CN})_{6}$, and $0.5 \% \mathrm{X}$-gal. Sections were washed and counterstained with Nuclear Fast Red (Vector Labs; Burlingame, CA). Sections from $c-m y c^{+/+} ; A l b-\mathrm{Cre}^{-/-}$;

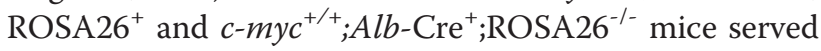
as negative controls.

\section{$\beta$-galactosidase analyses}

$\beta$-gal ELISA assays were performed using a kit obtained from Roche (Indianapolis, IN). Briefly, livers were obtained from 6-8 week old $c-m y c^{f l f f l}$; Alb-Cre;ROSA26 mice and homogenized by hand using a ground glass homogenizer with $2 \mathrm{ml} 1 \times$ Lysis buffer (Roche) per 40 $\mathrm{mg}$ tissue. Samples were incubated for $30 \mathrm{~min}$ at room temperature and centrifuged at 13,000 rpm for $15 \mathrm{~min}$ at $4^{\circ} \mathrm{C}$. Samples were split into aliquots and frozen in dry ice/ethanol before transferring to $-80^{\circ} \mathrm{C}$. An aliquot was used to determine the protein concentration using the bicinchoninic acid method (Pierce; Rockford, IL). $\beta$ gal ELISA assays were performed according to the manufacturer's directions using $5 \mu \mathrm{g}$ of liver homogenate.

\section{Statistical analyses}

Statistical analyses were performed using GraphPad Prism (San Diego, CA). One-way ANOVA with a post hoc Bonferroni Multiple Comparison test was performed for comparing the relative abundance of the $c$ $m y c^{f l}$ allele by qPCR. Comparisons of the relative abundances of $c-m y c$ and cre expression in mice of various genotypes were performed using a Mann-Whitney test. A Spearman rank correlation test was performed to assess the association between $c-m y c$ and cre abundance. For results where differences were not significant, no $p$ value is reported.

\section{Results}

\section{Deletion of hepatic c-myc}

Deletion of murine $c-m y c$ by gene targeting results in embryonic lethality at embryonic day 9-10 [23]. In order to assess the functional role of $\mathrm{c}-\mathrm{Myc}$ in adult mouse liver, we utilized a transgenic mouse line where Cre recombinase is under the control of the Albumin promoter [18]. Conditional deletion of $c-m y c$ was achieved by crossing these mice with $c-m y c^{f l f l}$ mice. The F1 generation was intercrossed to obtain $c-m y c^{f l / f l} ; A l b-\mathrm{Cre}^{+}$ and littermate control mice $\left(c-m y c^{f l / f l} ; A l b-\mathrm{Cre}^{-/-}, c-m y c\right.$ $\left.{ }^{+/+} ; A l b-\mathrm{Cre}^{+}\right)$. The $c-m y c^{f l / f l} ; A l b-\mathrm{Cre}^{+}$and $c-m y c^{+/+} ; A l b-$ $\mathrm{Cre}^{+}$lines were also bred to be homozygous for the Cre transgene. Litters contained the expected frequency of control and experimental animals.

Cre-mediated recombination of the $c-m y c$ locus was assessed using a qPCR strategy. Primers (XY) were designed to amplify a region of the $c-m y c$ locus upstream of the 5 loxP site. A second primer pair (NB) was designed surrounding the 3 ' loxP site such that Cre-mediated recombination of the locus would result in a decrease of the NB qPCR product (Figure 1A). Results revealed a significant decrease in the relative abundance of the NB product compared to the XY product in conditional knockout animals, indicating recombination of the $c-m y c$ locus.

By one month of age, recombination approached $70 \%$ in both male and female $c-m y c^{f l / f l} ; A l b-\mathrm{Cre}^{+}$ expressing mice, while recombination in $c$-myc $c^{f l f l} ; A l b$ $\mathrm{Cre}^{+/+}$mice was significantly higher (Figure 1A). 

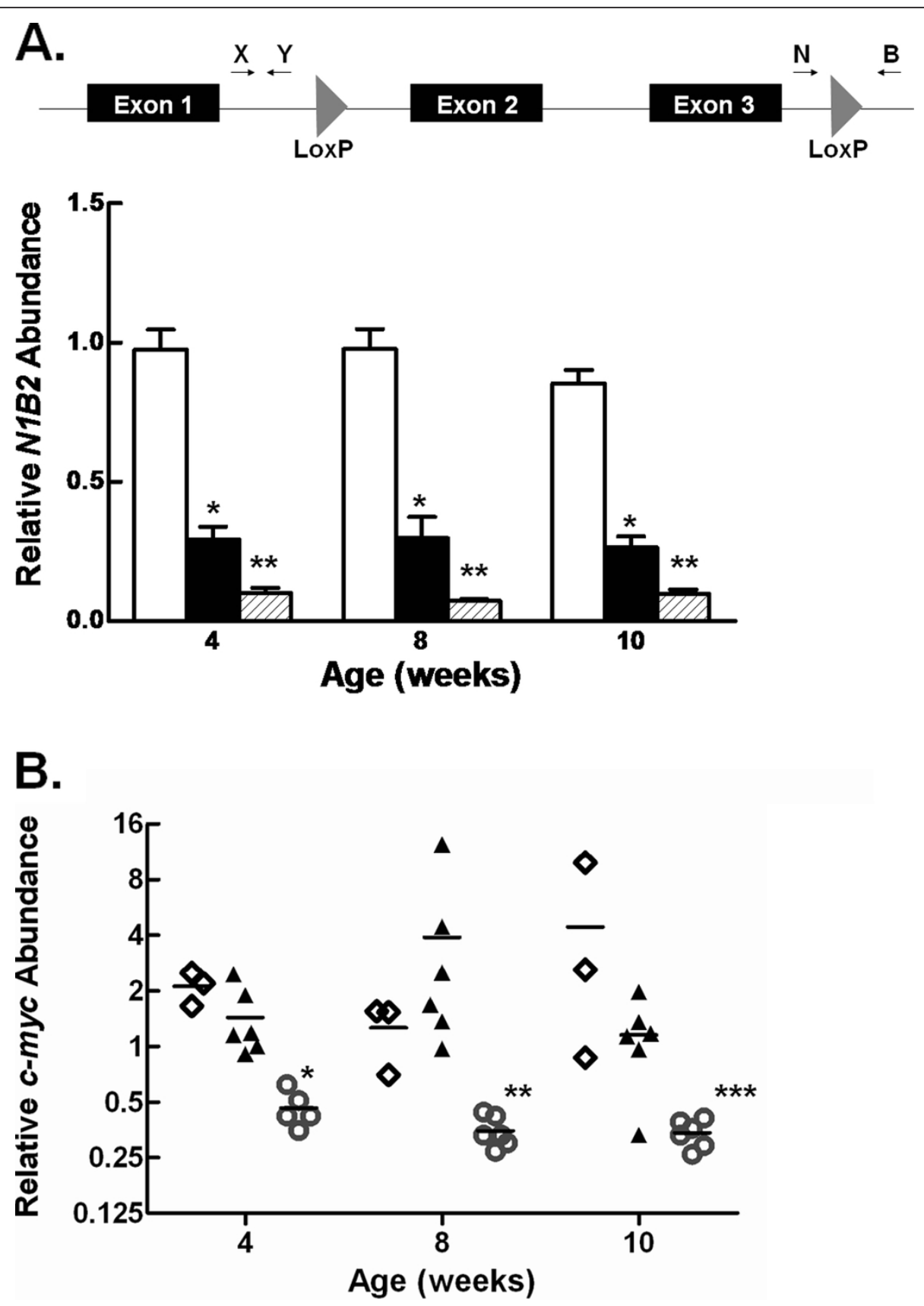

Figure 1 Hepatic c-myc deletion in $c-m y c^{f l / f l} ; A l b$-Cre expressing mice. A. Schematic representation of the $c-m y c^{f l}$ allele showing location of primer pairs used in GPCR analyses to determine the relative abundance of the $c-m y c^{f l}$ allele. The graph shows the quantification of the $c-m y c^{f l}$

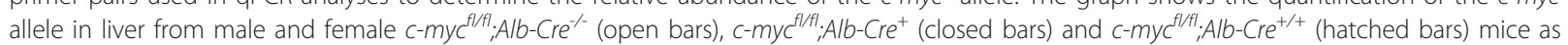

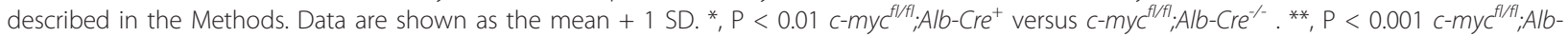
$\mathrm{Cre}^{+}$compared to $c-m y c^{f / f / f} ; A / b-C r e^{+/+}$. B. Hepatic c-myc expression in male and female control and $c-m y c^{f / f / f} ; A / b-C r e$ expressing mice as analyzed by RT-qPCR. Data are shown as individual points with the mean. $\nabla, c-m y c^{f l / f l} ; A l b-C r e^{-1 /} ; \mathbf{\Delta}, c-m y c^{+/+} ; A l b-C r e ; 0, c-m y c^{f l / f l} ; A l b-C r e .{ }^{*}, P=0.0014$ wk $c^{-}$

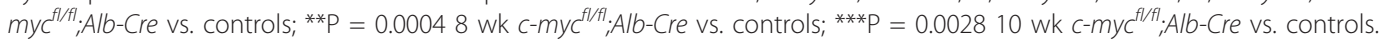

Consistent with previous findings on the temporal expression of the Albumin-Cre transgene [24], a similar deletion efficiency was observed in 8 and 10 week old conditional knockout animals, indicating that maximal recombination had been reached by one month of age. Since hepatocytes make up approximately $85 \%$ of the total cell population in liver, we estimated that recombination of the $c-m y c$ locus was near $80 \%$ in $c$ $m y c^{f l / f l} ; \mathrm{Alb}-\mathrm{Cre}^{+}$and over $90 \%$ in $m y c^{f l / f l} ; \mathrm{Alb}^{-\mathrm{Cre}^{+/+}}$ mice. 
To examine the influence of Cre-mediated recombination on $c-m y c$ mRNA, RT-qPCR was performed on total RNA isolated from livers obtained from control (c-myc $\left.{ }^{+/+} ; A l b-\mathrm{Cre}^{+/+}, c-m y c^{f l / f l} ; A l b-\mathrm{Cre}^{-/-}\right)$and $c-m y c^{f l / f l} ; A l b-C r e$ ${ }^{+/+}$mice at 4,8 , and 10 weeks of age (Figure 1B). A 75\% reduction in $c-m y c$ expression in livers from $c-m y c^{f l / f l}$; $A l b-\mathrm{Cre}^{+/+}$male and female mice was observed at one month of age and this reduction in $c-m y c$ expression remained stable in the liver through 10 weeks of age.

We assessed the effect of the model on c-Myc protein levels by immunoprecipitating $\mathrm{c}-\mathrm{Myc}$ from total liver homogenates prepared from 4 week old $c-m y c^{f l / f l} ; A l b$ $\mathrm{Cre}^{+/+}$and $c-m y c^{+/+} ; A l b-\mathrm{Cre}^{+/+}$mice (data not shown). $c-M y c$ protein content was low in four week old $c-m y c$ ${ }^{+/+}$; Alb-Cre ${ }^{+/+}$control mice and below the level of detection in $c-m y c^{f l / f l} ; A l b-\mathrm{Cre}^{+/+}$mice.

\section{Characterization of hepatic c-myc knockout mice}

Our prior studies in the rat showed that c-Myc protein was expressed in quiescent adult hepatocytes, suggesting a functional role for the protein in adult liver other than its role in proliferation [16]. Given the established role of $c$ - $m y c$ in hepatic proliferation and growth, we measured liver weight to carcass weight ratios in male and female $c$ $m y c^{f l f f l} ; \mathrm{Alb}-\mathrm{Cr} e^{+}, c-m y c^{f l / f l} ; \mathrm{Alb}-\mathrm{Cr}^{+/+}$and control mice from one month of age through the first year of life. Liver weight to carcass weight ratios were similar in $c-m y c^{f l / f l}$ $A l b$-Cre expressing and control mice at all ages analyzed (Figure 2). Despite the increased recombination of the $c$ $m y c$ locus in $c-m y c^{f l / f l}$;Alb-Cre homozygous mice, no difference in liver weight was observed in these animals compared to $c-m y c^{f l / f l} ; A l b-C r e$ hemizygous mice.

$\mathrm{c}-\mathrm{Myc}$ has been shown to regulate genes involved in glucose metabolism and to be involved in the regulation of cell and nucleolar size $[12,25]$. In order to determine if loss of c-Myc would result in alterations in glucose homeostasis we analyzed serum glucose levels in fed $c-m y c^{f l / f l}$ and $c-m y c^{+l+} A l b-C r e$ expressing mice at 4 and 8 weeks of age. Serum glucose was unaffected in the $c-m y c^{f l / f l} ; A l b-C r e$ expressing mice at both ages $(277 \pm 19$ vs. $271 \pm 73.6$ and $305 \pm 27$ vs. $295 \pm 20$; 4 and 8 weeks respectively).

To investigate whether the organization of the liver parenchyma or hepatocyte morphology was affected in $c-m y c$ conditional knockout mice, hematoxylin and

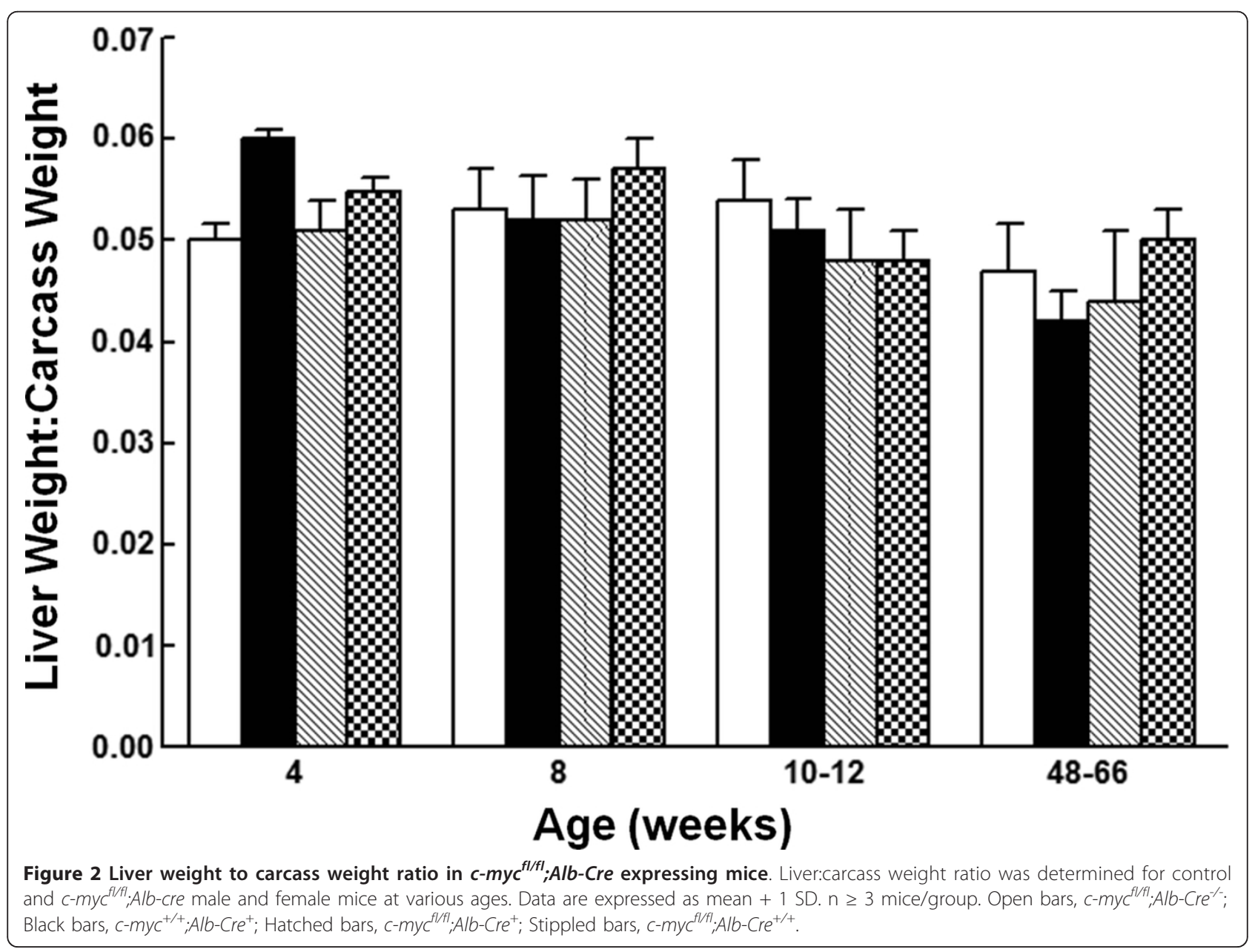


eosin stained liver sections were prepared from $c-m y c^{f l / f l}$; Alb-Cre expressing and control mice at 4, 8, and 10 weeks of age (data not shown). The gross and histological appearance of the liver were similar in $c-m y c^{f l / f l} ; A l b$ Cre expressing and control animals as well as $c-m y c^{f l / f l}$; Alb-cre hemizygous compared to homozygous animals.

\section{$c-m y c^{f l / f I} ; A l b$-Cre expressing hepatocyte response to nonproliferative and proliferative stimuli}

We extended our studies to determine the effect of reducing $\mathrm{c}-\mathrm{Myc}$ in a nonproliferative model of liver growth, refeeding after a $48 \mathrm{hr}$ fast. Previous studies in our laboratory have shown that rat liver growth during refeeding requires rapid and marked induction of ribosomal biogenesis and translation initiation, two processes where c-Myc has been proposed to have a functional role [26]. Eight week old $c-m y c^{f l / f l}$ and $c-m y c$ ${ }^{+l+}$ Alb-Cre expressing mice of both sexes were divided into three groups. Mice were either fed ad libitum (control), fasted for $48 \mathrm{hr}$, or refed ad libitum for $24 \mathrm{hr}$ following a $48 \mathrm{hr}$ fast (refed). As no difference in liver weight to carcass weight ratio or total liver protein was observed in $c-m y c^{f l / f l}$ animals carrying one or two alleles of the Alb-Cre transgene, the data from these animals were combined. In agreement with our previous data in the rat [26], fasting for $48 \mathrm{hr}$ resulted in a slight reduction in liver to carcass weight ratio in both control and $c-m y c^{f l f l} A l b$-Cre expressing animals. Refeeding for 24 hr resulted in restoration of liver weight to carcass weight ratio to the level of the control fed mice in both $c-m y c^{f l f l}$ and $c-m y c^{+l+}$ animals (Figure 3A). Total liver protein decreased by approximately $40 \%$ in both genotypes with fasting. Recovery of total protein was attained after $24 \mathrm{hr}$ of refeeding in both genotypes, suggesting that full expression of $c-m y c$ is not required for protein synthesis in this model of liver growth (Figure 3B).

Quiescent adult hepatocytes rapidly enter the cell cycle in response to a reduction in liver mass. Upregulation of c-Myc protein content is an early event in this process, suggesting the hypothesis that liver regeneration following partial hepatectomy requires c-Myc $[11,15]$. To test this hypothesis, eight to ten-week old male $c$ $m y c^{+l+}$ and $c-m y c^{f l / f l} A l b-C r e$ expressing animals underwent 2/3 partial hepatectomy. Mice were sacrificed 24, 48 , or $96 \mathrm{hr}$ post-hepatectomy. Liver weight to carcass weight ratios were determined (Figure 4A). No difference in liver to carcass weight ratio between $c-m y c^{f l f f l}$; Alb-Cre expressing and control mice was observed at any of the timepoints analyzed. However, a slight decrease in the number of Ki-67 positive hepatocytes was observed in the $c$-myctlfl mice compared to wildtype mice $48 \mathrm{hr}$ post-hepatectomy (Figure 4B). To determine if cells lacking in $c-m y c$ were responsible for liver regeneration, we quantified $c-m y c$ deletion in each mouse in the regenerated liver and liver excised at the time of partial hepatectomy. We found that the regenerating liver was as deficient in the $c-m y c$ allele as was the liver excised at the time of surgery [average fold change $(0.84 \pm 0.82 ; 0.80 \pm 0.93 ; 0.78 \pm 0.86) 24,48,96 \mathrm{hr}$, respectively]. The persistent loss of the $c$-myc allele was consistent with the conclusion that the recovered liver mass was arising from $c-m y c$-deficient cells. Despite any modest decrease in the number of hepatocytes in the cell cycle, the absence of an effect on the recovery of liver weight indicates that the liver is capable of regeneration despite a significant reduction in $c-m y c$. As in the non-proliferative model, there was no difference in mice containing one versus two alleles of the Alb-Cre transgene. Liver sections obtained from mice placed on the fasting/refeeding protocol and from animals subjected to $2 / 3$ partial hepatectomy did not reveal disorganization of the liver parenchyma or any other obvious changes in hepatocyte morphology between $c$-myc $c^{f l / f l}$ and $c-m y c^{+l+}$ Alb-Cre expressing mice (Figure 5).

\section{Expression of members of the c-myc/max/mad network}

We went on to explore whether the lack of an effect of reducing $c-m y c$ on hepatocyte proliferation, growth, and protein synthesis could be accounted for by compensatory induction of other myc family members or the cMyc binding partner Max. We had previously found that max expression at both the RNA and protein level correlated with hepatocyte proliferation during rat liver development and that overexpression of max induced a shift in $\mathrm{c}-\mathrm{Myc}$ localization from the nucleolus to the nucleus [15]. These data raise the possibility that compensatory induction of Max could increase c-Myc activity. Multiplex RNase protection assays were performed on total RNA isolated from 8 and 10 week old $c-m y c^{f l / f l}$ and $c-m y c^{+l+} A l b$-Cre expressing animals of both sexes (Figure 6). Two of the $m y c$ family members, $B-m y c$ and $L-m y c$ were expressed in murine liver, while $N-m y c$ expression was below the level of detection in our assay. There was no difference in the expression of these family members or of $\max$ in $c-m y c^{f l f l}$ compared to wild-type $c-m y c$ Alb-Cre expressing mice.

There is substantial overlap between the role of c-Myc and $\mathrm{Wnt} / \beta$-catenin signaling in the regulation of postnatal liver development, hepatic organization, and liver regeneration [27]. In addition, c-myc is a downstream target of $\beta$-catenin [28]. Given the interaction between $c$-myc and $\beta$-catenin, we investigated whether deletion of $c-m y c$ is compensated by upregulation of $\beta$-catenin signaling. Immunohistochemical analysis for $\beta$-catenin was performed on liver sections from wild-type and $c$ $m y c$ deficient mice. No difference in the localization of $\beta$-catenin was observed between the two genotypes of mice. These results were confirmed by Western 


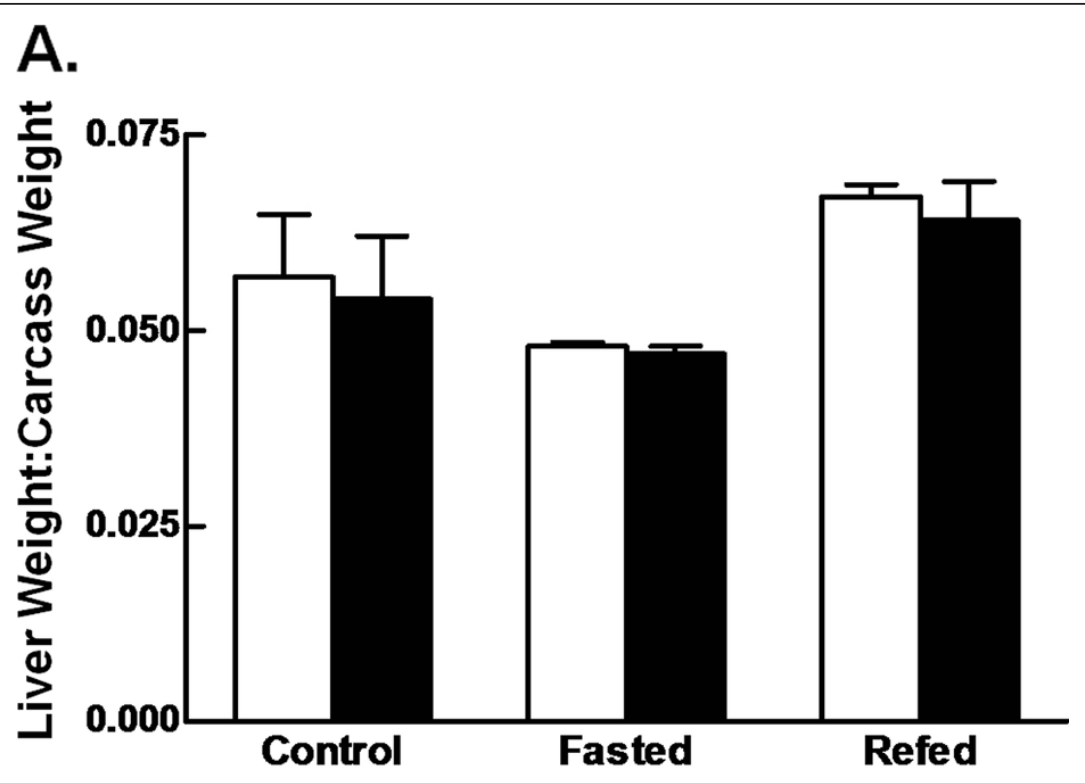

B.

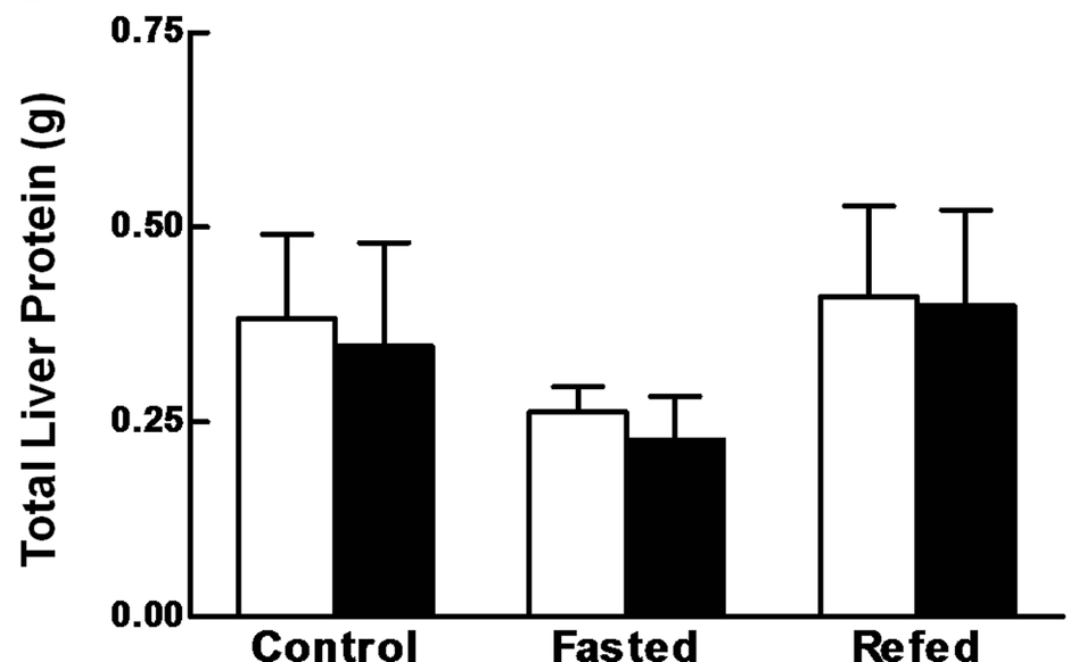

Figure 3 Effect of conditional c-myc deletion on liver growth following starvation. Male and female mice were fed ad libitum (control), fasted for $48 \mathrm{hr}$ (fasted), or fasted for $48 \mathrm{hr}$ then refed ad libitum for $24 \mathrm{hr}$ (refed). A. The graph shows liver:carcass weight ratios for c-myc $\mathrm{c}^{+/+}$ (open bars) and c-myc $c^{f / f l}$ (closed bars) Alb-Cre expressing mice expressed as the mean $+1 \mathrm{SD} . \mathrm{n} \geq 3$ mice/group. B. Liver homogenates were prepared and protein concentration determined using the bichoninic acid method. Total liver protein was then calculated based on total liver weight. The graph shows total liver protein content for $c-m y c^{+/+}$(open bars) and c-myc $c^{f / f l}$ (closed bars) Alb-Cre expressing mice expressed as the mean +1 SD. $n \geq 3$ mice/group.

immunoblotting of nuclear and post-nuclear fractions prepared from liver of wild-type and $c$-myc deficient mice (data not shown).

\section{Effect of $c-m y c^{f l / f l}$ on Cre expression}

Numerous studies using the Alb-Cre transgene to delete various genetic loci involved in hepatocyte proliferation, growth, and survival have reported recombination nearing $100 \%$ and complete ablation of the expression of the gene of interest [29-31]. Given our results, which varied markedly from published experience, we investigated the expression and activity of the Alb-Cre transgene in $c-m y c$ ${ }^{+/+}$and $c-m y c^{f l / f l}$ mice to ascertain whether floxing $c-m y c$ had an effect on the expression of the Alb-Cre transgene such that $c-m y c$ deletion would be impaired in our model. RNA was isolated from livers obtained from $c-m y c^{+/+} ; A l b$ $\mathrm{Cr}^{+/+}$and $c-m y c^{f l f f l} ; \mathrm{Alb}-\mathrm{Cr}^{+/+}$animals at 4,8 , and 10 weeks of age. RT-qPCR was performed to assess cre 

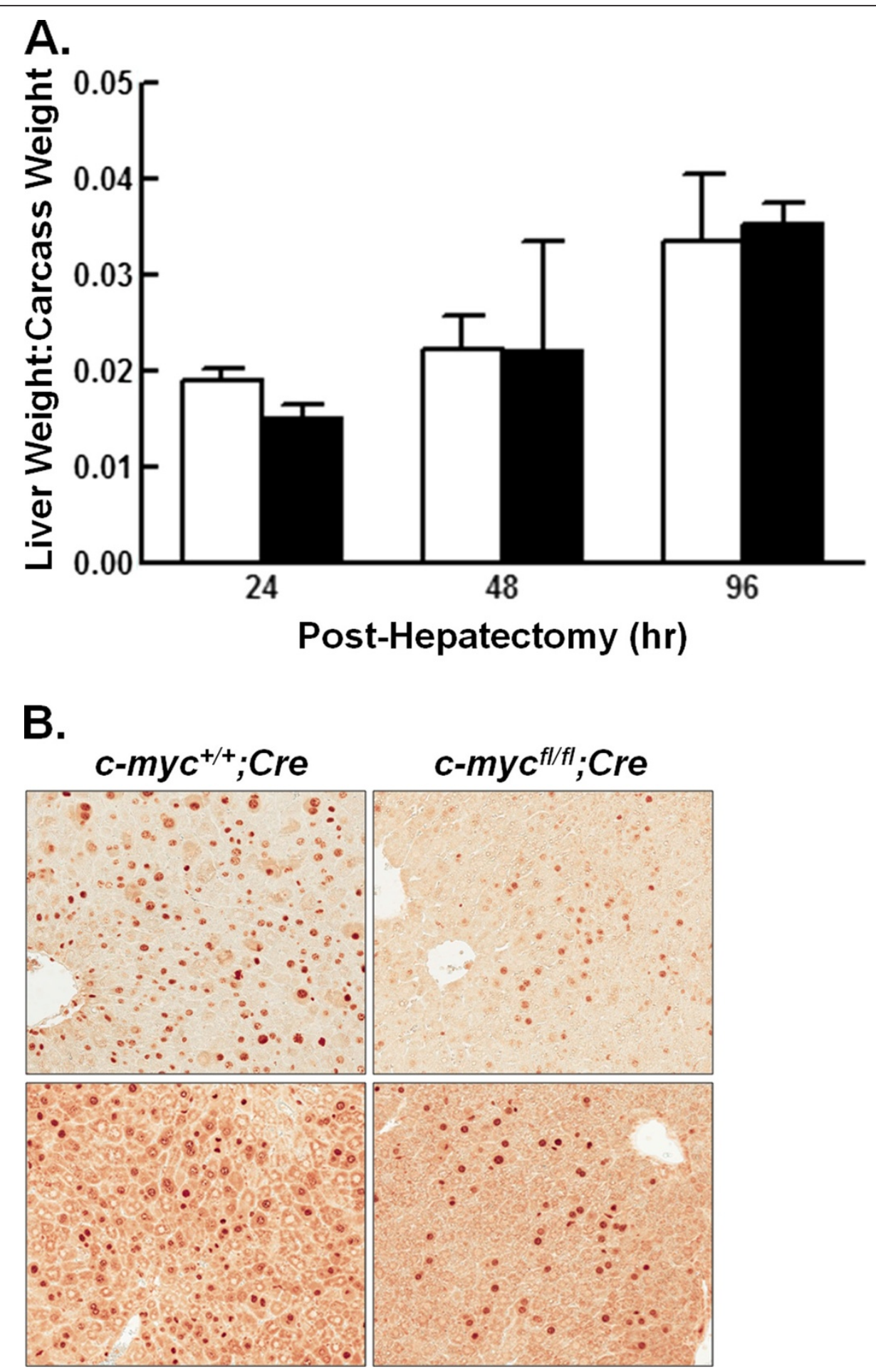

Figure 4 Effect of conditional c-myc deletion on liver regeneration. Male mice were subjected to $2 / 3$ hepatectomy and assessed 24,48 , or $96 \mathrm{hr}$ after resection. A. The graph shows liver:carcass weight ratio for c-myc $c^{+/+}$(open bars) and c-myc $c^{f / f l}$ (closed bars) Alb-Cre expressing mice.

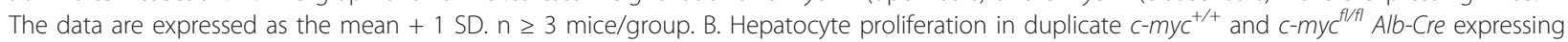
mice $48 \mathrm{hr}$ post-hepatectomy as assessed by Ki-67 immunohistochemistry. Representative 20x images are shown. 


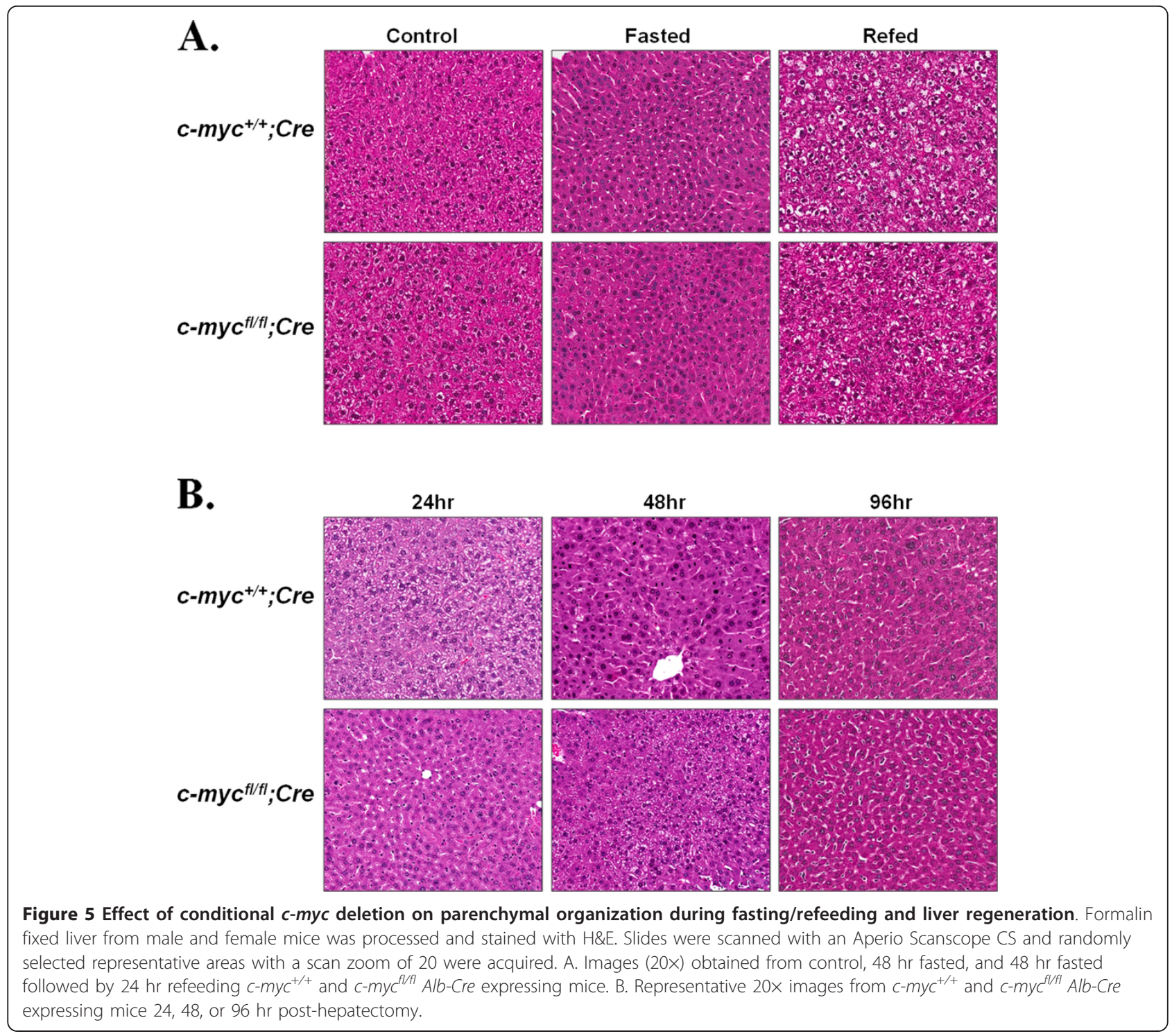

expression (Figure 7A). A statistically significant difference in cre expression was observed in $c$-mycllfl compared to $c$ $m y c^{+/+}$mice at 4 weeks of age suggesting that deletion of $c-m y c$ suppressed expression of the Alb-Cre transgene. At 8 and 10 weeks of age there was no statistically significant difference in cre expression between $c-m y c^{f l f l}$ and $c-m y c$ ${ }^{+/+}$mice. However, in comparison to 4-week old animals, cre expression in older mice varied considerably from animal-to-animal.

To ascertain whether the variation in cre expression correlated with the amount of c-myc we compared the relative abundance of $c r e$ and $c-m y c$ in individual $c$ $m y c^{f l / f l} ; \mathrm{cre}^{+/+}$mice at 4,8 , and 10 weeks (Figure 7B). This analysis revealed a significant association between floxing $c-m y c$ and the expression of $c r e$ (Spearman $\mathrm{r}=$ $-0.6609, \mathrm{p}=0.0019$ ).
We further characterized the pattern of Cre activity in our model by crossing our mice to the ROSA26 reporter line. The ROSA26 line has a lacZ gene that is expressed when an upstream stop codon is removed by Cremediated recombination. In order to study the effect of floxing $c-m y c$ on Cre activity, mice were further crossed to obtain $c-m y c^{f l / f l} ; A l b$-Cre;ROSA26 and $c-m y c^{+/+} ; A l b$ Cre;ROSA26 mice. Sections prepared from six-week old mice were stained for $\beta$-galactosidase activity using $X$ gal. Analysis revealed a wide pattern of LacZ-staining across $20 \times$ fields of individual sections in both genotypes of mice (Figure 8). In some fields, the majority of the hepatocytes displayed intense nuclear and cytoplasmic staining while other hepatocytes exhibited weak cytoplasmic staining. There were also fields where many of the hepatocytes appeared negative for Lac-Z staining. 

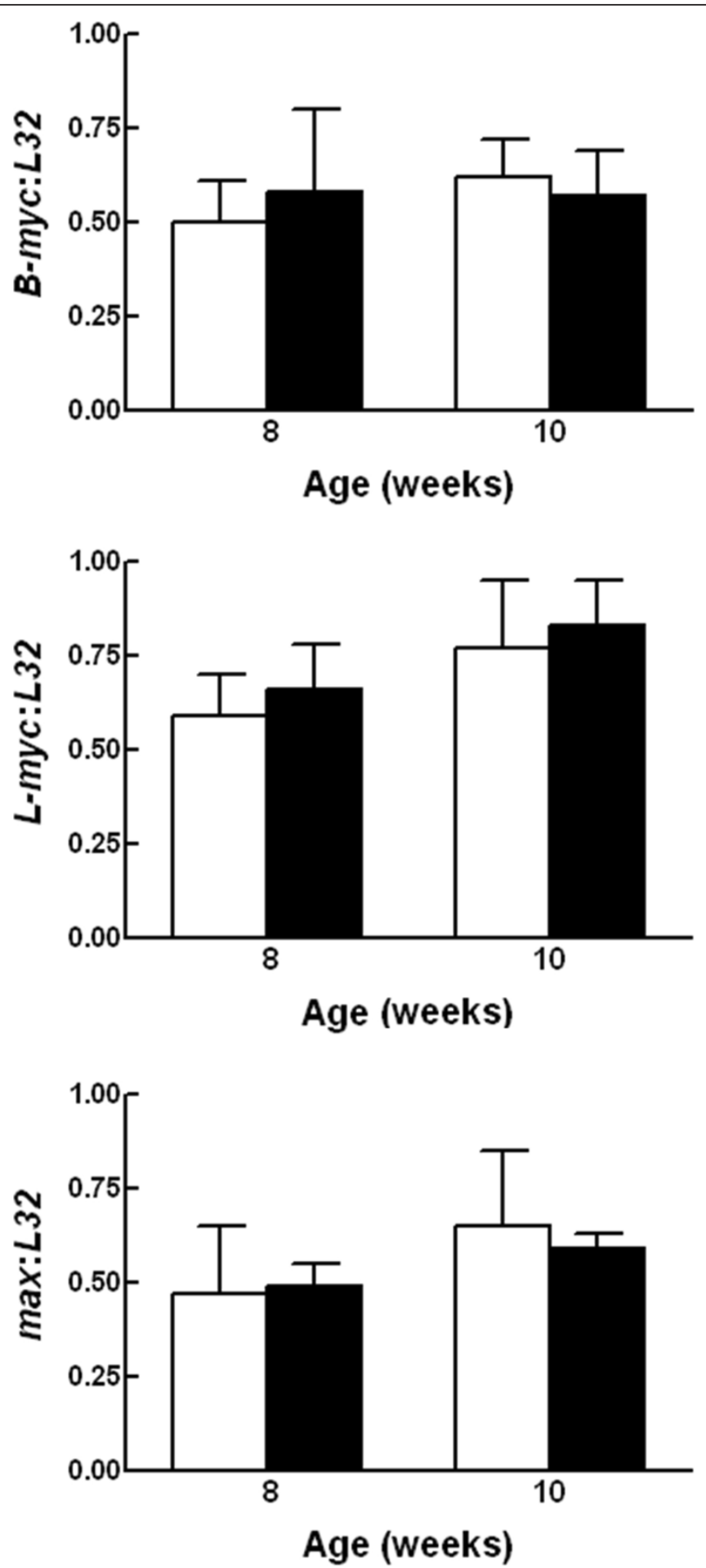

Figure 6 Expression of members of the c-myc/max/mad network in liver derived from male and female control and c-myc conditional knockout mice. Total liver RNA was isolated from triplicate c-myc wild-type (open bars) and c-myct/ffl (closed bars) Alb-Cre expressing mice at 8 and 10 weeks of age and a multiprobe RNase protection assay performed. Expression levels of B-myc, L-myc, and max were quantified and normalized to the internal control L32. Data are expressed as mean +1 SD. 


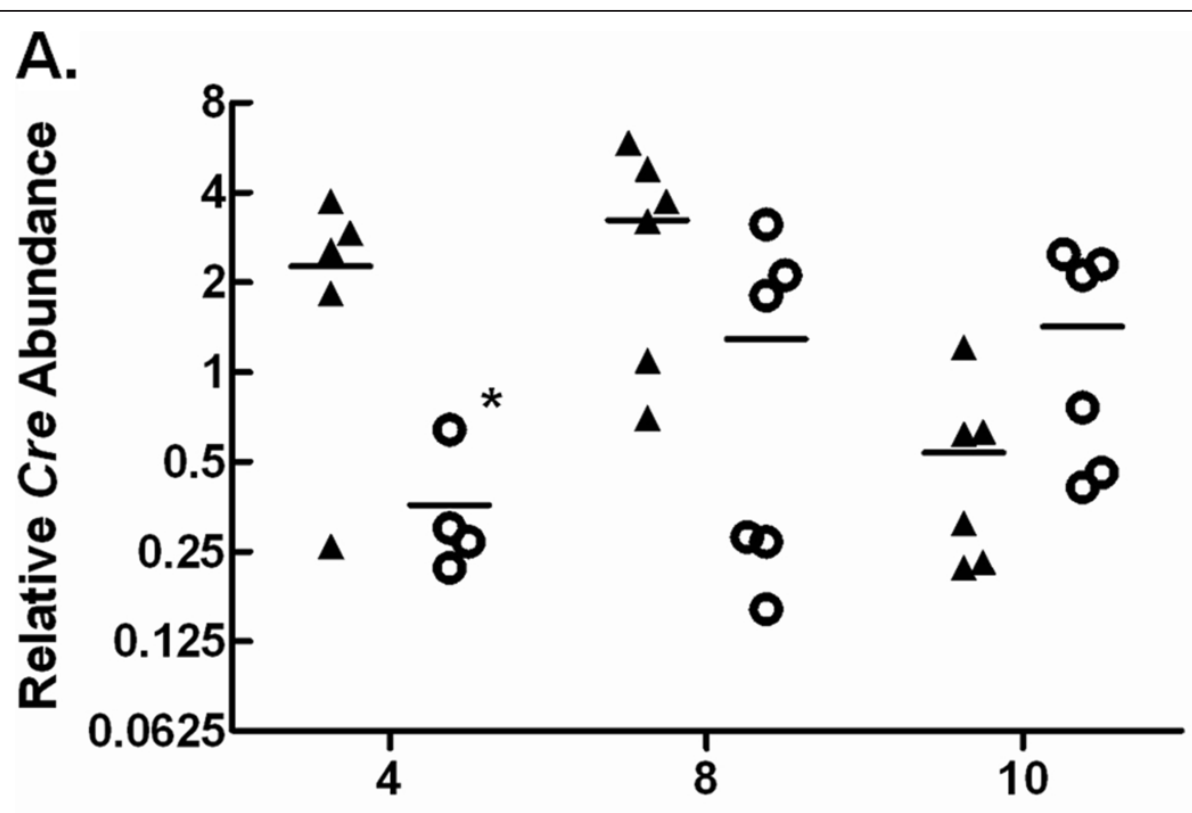

\section{Age (weeks)}

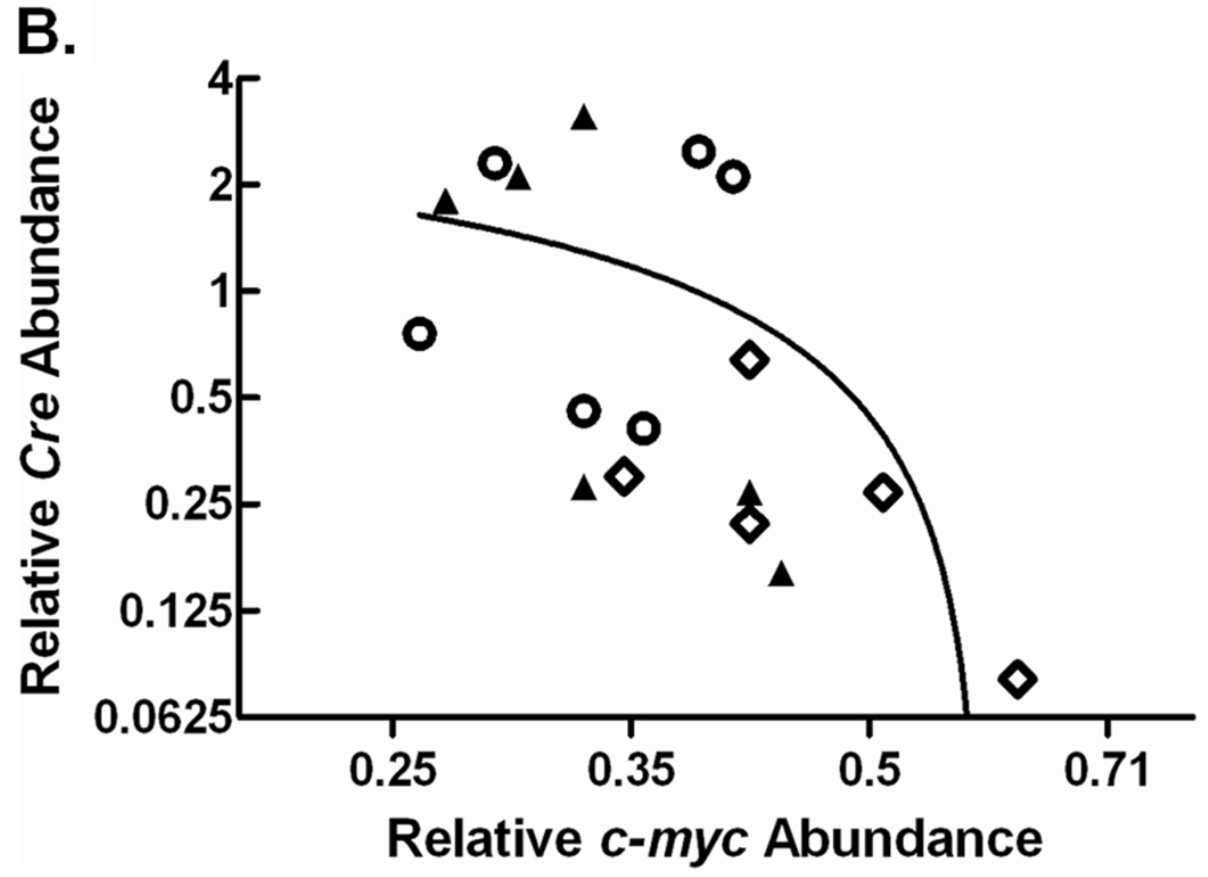

Figure 7 Cre expression in c-myc conditional knockout and control mice. A. Total liver RNA was isolated from male and female $c-m y c^{+/+}$;

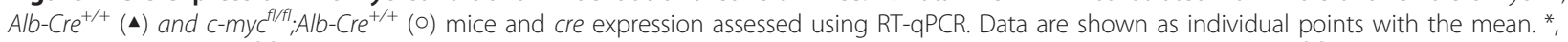

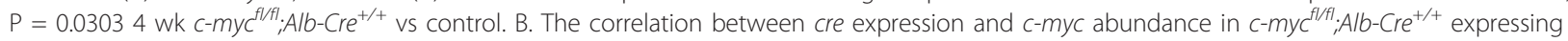
mice at 4,8 and 10 weeks of age. Data are expressed as individual points. $\diamond, 4$ weeks; $\mathbf{\Delta}, 8$ weeks; $\odot, 10$ weeks.

In light of the qualitative nature of the Lac- $Z$ staining, we prepared liver homogenates from 6-8 week old mice and performed $\beta$-gal ELISA assays in order to quantitate Cre activity (data not shown). No difference in B-gal content was found in the $c-m y c^{f l / f l} ; A l b$-Cre;ROSA26 versus the $\mathrm{c}-m y \mathrm{c}^{+/+} ; \mathrm{Alb}$-Cre;ROSA26 controls.

\section{Discussion}

The transcription factor c-Myc has long been assigned a prominent role in the synchronous hepatocyte proliferation that occurs during liver regeneration $[9,11]$. A series of in vivo studies performed in our laboratory characterizing the regulation of the $c-m y c / m a x / m a d$ 


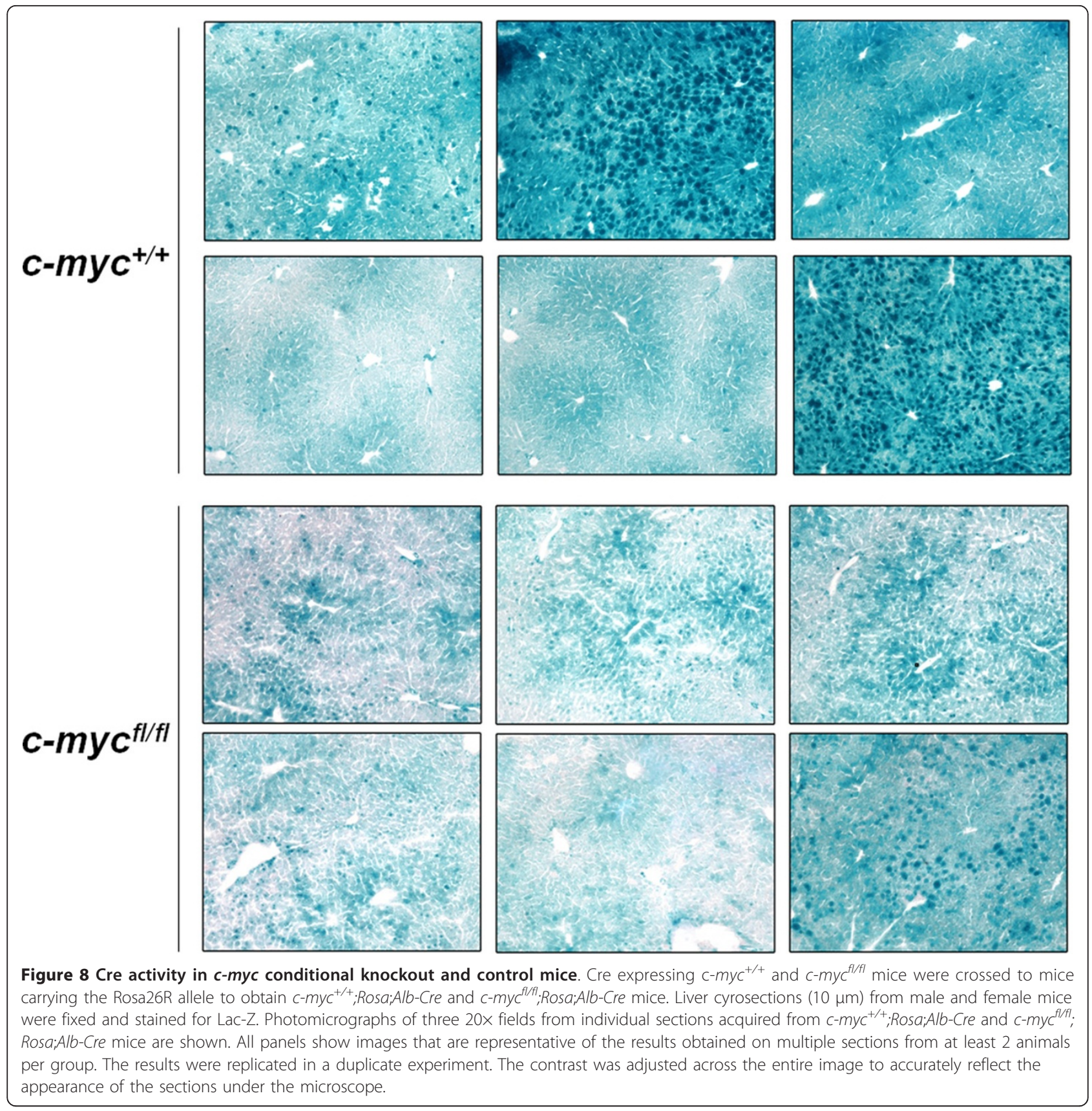

network in fetal and adult liver revealed that c-Myc was present in quiescent adult hepatocytes and was localized to the nucleolus [16]. These studies led us to hypothesize a functional role for $\mathrm{c}-\mathrm{Myc}$ in adult liver that was independent of its role in proliferation. In order to test this hypothesis, we generated a conditional knockout using floxed $c-m y c$ and Albumin-Cre mice. This approach led to significant reduction in $c-m y c$ expression one month after birth in $c-m y c^{f l / f l} ; A l b$-Cre expressing mice. We observed greater recombination efficiency in $c-m y c^{f l f l} ; A l b$-Cre homozygous compared to hemizygous animals. However, there was no difference in liver weight ratios during development in $c-m y c^{f l f l}$; Alb-Cre $e^{+/+}$compared to $c-m y c^{f l / f l} ; \mathrm{Alb}-\mathrm{Cr} e^{+}$animals. As we did not observe differences in these two groups in regards to histology, liver regeneration or the recovery from fasting, the animals were grouped together for comparison with $c$-myc wild-type Alb-Cre expressing mice. There was a low level of residual $c-m y c$ that persisted in $c-m y c^{f l f f l} ; A l b-C r e$ expressing livers even up to four months. This residual level may be a result of expression in nonparenchymal cells or a subset of 
hepatocytes in which the albumin promoter is not expressed. However, we were unable to exclude a low level of $c-m y c$ expression in the larger population of hepatocytes. Interestingly, floxed $c-m y c$ had an inhibitory effect on Cre expression in one month old mice. In contrast, in older animals Cre expression was extremely variable regardless of $c-m y c$ status. This variation may be a result of age-dependent silencing of the Cre transgene.

Variegation of transgene expression is a well documented phenomenon in many lines of transgenic mice [32-34] although the cause and mechanism is not known. In a mouse model where lac $Z$ was driven by the $\beta$-globin promoter, there was a general tendency of decreased transgene expression with age [35]. In contrast to other reports on variable transgene expression, we observed a negative effect of our floxed gene on Cre recombinase expression. We speculate that this effect is a result of a selective pressure to retain $c-m y c$ in hepatocytes. It is possible that this selective effect could manifest itself in ways other than an effect on Cre expression.

There was no apparent phenotypic effect of significantly reducing $c$-myc in hepatocytes. The livers of $c$ $m y c^{f l f l} ; A l b$-Cre expressing and control mice were of similar size and histology, consistent with the conclusion that $c-m y c$ is not required for hepatocyte proliferation during normal liver growth and maintenance. We used two models, partial hepatectomy and liver growth following refeeding to determine c-Myc function in the presence or absence of a proliferative stimulus. c-Myc has been considered to have a prominent role in the hepatocyte proliferation that occurs during liver regeneration. After partial hepatectomy there was a slight decrease in the number of hepatocytes in the cell cycle at $48 \mathrm{hr}$. However, no delay in the restoration of liver mass was observed, indicating that $c-m y c$ is not required for liver regeneration following $2 / 3$ partial hepatectomy. While these studies were in progress, two conflicting reports were published on the effect of deleting $c$-myc on liver regeneration. Baena et al. found that deletion of $c-m y c$ resulted in impaired liver regeneration [36]. However, $\mathrm{Li}$ et al. reported a total restoration of liver mass by 7 days post-resection in mice where floxed $c$-myc was deleted using adenoviral Cre [37]. In contrast to our study and Li et al., where liver/body mass ratio was used as the outcome measurement for liver regeneration, Baena et al. used PCNA and Cyclin A content as an indirect measure of hepatocyte proliferation. Furthermore, the content of these proteins was only determined 2 day post-hepatectomy leaving it unclear whether liver regeneration would have been affected at later time points. Taken together, these studies indicate that $c-m y c$ is not essential for restoration of liver mass during regeneration.
In some systems, changes in $c-m y c$ content affect cell size without affecting cell proliferation [38]. In order to assess the function of $\mathrm{c}-\mathrm{Myc}$ in a non-proliferative model of hepatocyte growth, mice were fasted for $48 \mathrm{hr}$ followed by a $24 \mathrm{hr}$ refeeding period. In accordance with our published data in the rat, a $48 \mathrm{hr}$ fast resulted in decreased liver/body mass ratio and liver protein content while refeeding resulted in restoration of liver mass and protein despite a significant reduction in $c-m y c$. cMyc has been proposed to play a role in essential processes leading to hepatocyte growth, such as, ribosomal biogenesis and protein synthesis. Kim et al found that transient $c-m y c$ overexpression in mouse liver led to hepatocyte hypertrophy, the induction of ribosomal genes, and increased protein synthesis [12]. Our results indicate that protein synthesis and hepatocyte growth can occur in spite of a significant reduction in $c-m y c$, raising the notion that overexpression of $\mathrm{c}-\mathrm{Myc}$ may result in the activation of gene regulatory networks and pathways not normally controlled by c-Myc in adult hepatocytes.

Studies by Murphy et al. led to the conclusion that the level of $c-m y c$ expressed in a cell is crucial to its biological effect [39]. These studies used a mouse model where the activation of Cre recombinase results in the expression of a tamoxifen inducible MycER fusion protein with the amount of c-Myc expressed dependent on whether the mouse carried one or two MycER alleles. The authors report that modest increases in c-Myc can activate cellular proliferation while a higher threshold is needed to stimulate apoptosis. This study suggests that a high level of c-Myc may lead to the binding of a different set of target genes from those regulated by endogenous levels of c-Myc. This notion is further supported by studies on the role of c-Myc in hepatocarcinogenesis. Deregulation of c-Myc through gains in copy number, point mutations, and transactivation by viral proteins is observed in $30-60 \%$ of human hepatocellular carcinomas (HCC) $[40,41]$. Although its role in the development of human $\mathrm{HCC}$ is unclear, studies in transgenic mice have shown that overexpression of this oncogene results in increased hepatocyte proliferation, genomic instability and apoptosis. The paradoxical activation of cellular proliferation and growth in concert with apoptosis leads to the requirement of secondary mutations for tumor development $[42,43]$.

Our studies do not rule out a subtle effect of deleting $c-m y c$ on other aspects of liver physiology. It is possible that $c$-myc deletion affects other pathways. cMyc has been shown to regulate many genes involved in liver metabolism and can ameliorate the effects of diabetes on glucose metabolism in mice $[25,44]$. Regardless of potential effects on other pathways 
overall adult liver physiology appeared to be unaffected by $c$-myc deletion.

Studies performed to assess the requirement and function of c-Myc in other mature tissues suggest that the role of this protein in proliferation, growth, and other cellular processes is cell-type dependent. Deletion of $c$ $m y c$ in the hematopoietic lineage results in defective hematopoiesis and angiogenesis leading to embryonic lethality while there was no requirement for $c-m y c$ in endothelial cells [45]. Moreover, normal adult intestinal homeostasis occurs in the absence of $c-m y c$, yet $c-m y c$ is required for the formation of intestinal crypts [46]. These studies lead to the conclusion that the in vivo targets of $c-m y c$ will vary based on cell type and developmental stage thus adding another layer of complexity to understanding the functional role of $c-m y c$.

\section{Conclusions}

Our studies indicate that a reduction in hepatic $c$-myc does not affect normal postnatal liver growth and development. Furthermore, reducing this proto-oncogene does not affect the restoration of liver mass during liver regeneration or the restoration of liver protein following fasting. However, our studies do not rule out subtle effects of $c-m y c$ on liver metabolism or liver physiology. Decreasing $c-m y c$ correlated with a reduction in the expression of the Albumin-Cre transgene, suggesting a selective pressure to maintain $c$ $m y c$. Furthermore, this pressure may prevent the complete deletion of hepatic $c-m y c$ by traditional conditional knockout strategies.

\section{Acknowledgements \\ We thank Shu-Whei Tsai for assistance with the animal studies and Kate Brilliant for assistance with cryosections. We also thank Joan Boylan for helpful discussions and critical review of the manuscript. Support for this study was provided by National Institutes of Health grants R01HD24455 and R01HD35831 (to P.G.) and R01FM041690 (to JMS). JAS was supported by National Institutes of Health grant P20RR017695. Core facility support from the COBRE awards P20 RR015578 and P20 RR017695 is also gratefully acknowledged. \\ Author details \\ 'Department of Pediatrics, Rhode Island Hospital and Brown University, Providence, RI 02903, USA. ²Department of Molecular Biology, Cell Biology and Biochemistry, Brown University, Providence, RI 02912, USA. ${ }^{3}$ Center for Genomics and Proteomics, Brown University, Providence, RI 02912, USA. ${ }^{4}$ Department of Pathology, MacNeal Hospital, Berwyn, IL, USA.}

\section{Authors' contributions}

JAS, JMS and PG conceived the study. JAS performed all practical aspects of the study. CS contributed to design and analysis of GPCR assays. The manuscript was prepared by JAS and PG. All authors read and approved the final manuscript.

\section{Competing interests}

The authors declare that they have no competing interests.

Received: 14 November 2011 Accepted: 7 March 2012 Published: 7 March 2012
References

1. Mao DY, Watson JD, Yan PS, Barsyte-Lovejoy D, Khosravi F, Wong WW, et al: Analysis of Myc bound loci identified by CpG island arrays shows that Max is essential for Myc-dependent repression. Curr Biol 2003, 13:882-886.

2. O'Connell BC, Cheung AF, Simkevich CP, Tam W, Ren X, Mateyak MK, et al: A large scale genetic analysis of c-Myc-regulated gene expression patterns. J Biol Chem 2003, 278:12563-12573.

3. Grandori C, Cowley SM, James LP, Eisenman RN: The Myc/Max/Mad network and the transcriptional control of cell behavior. Annu Rev Cell Dev Biol 2000, 16:653-699.

4. Gregory MA, Xiao Q, Cornwall GA, Lutterbach B, Hann SR: B-Myc is preferentially expressed in hormonally-controlled tissues and inhibits cellular proliferation. Oncogene 2000, 19:4886-4895.

5. Prochownik EV: c-Myc as a therapeutic target in cancer. Expert Rev Anticancer Ther 2004, 4:289-302.

6. Lin CP, Liu JD, Chow JM, Liu CR, Liu HE: Small-molecule c-Myc inhibitor, 10058-F4, inhibits proliferation, downregulates human telomerase reverse transcriptase and enhances chemosensitivity in human hepatocellular carcinoma cells. Anticancer Drugs 2007, 18:161-170.

7. Ohgaki H, Sanderson ND, Ton P, Thorgeirsson SS: Molecular analyses of liver tumors in c-myc transgenic mice and c-myc and TGF-alpha double transgenic mice. Cancer Lett 1996, 106:43-49.

8. Collier JJ, Doan TT, Daniels MC, Schurr JR, Kolls JK, Scott DK: c-Myc is required for the glucose-mediated induction of metabolic enzyme genes. J Biol Chem 2003, 278:6588-6595.

9. Fausto N, Mead JE, Braun L, Thompson NL, Panzica M, Goyette M, et al: Proto-oncogene expression and growth factors during liver regeneration. Symp Fundam Cancer Res 1986, 39:69-86.

10. Steer CJ: Liver regeneration. FASEB J 1995, 9:1396-1400.

11. Thompson NL, Mead JE, Braun L, Goyette M, Shank PR, Fausto N: Sequential protooncogene expression during rat liver regeneration. Cancer Res 1986, 46:3111-3117.

12. Kim S, Li Q, Dang CV, Lee LA: Induction of ribosomal genes and hepatocyte hypertrophy by adenovirus-mediated expression of c-Myc in vivo. Proc Natl Acad Sci USA 2000, 97:11198-11202.

13. Riu E, Ferre T, Hidalgo A, Mas A, Franckhauser S, Otaegui P, et al: Overexpression of c-myc in the liver prevents obesity and insulin resistance. FASEB J 2003, 17:1715-1717.

14. Riu E, Bosch F, Valera A: Prevention of diabetic alterations in transgenic mice overexpressing Myc in the liver. Proc Natl Acad Sci USA 1996, 93:2198-2202.

15. Sanders JA, Gruppuso PA: Coordinated regulation of c-Myc and Max in rat liver development. Am J Physiol Gastrointest Liver Physiol 2006, 290 : G145-G155.

16. Sanders JA, Gruppuso PA: Nucleolar localization of hepatic c-Myc: a potential mechanism for c-Myc regulation. Biochim Biophys Acta 2005, 1743:141-150.

17. de Alboran IM, O'Hagan RC, Gartner F, Malynn B, Davidson L, Rickert R, et al: Analysis of C-MYC function in normal cells via conditional genetargeted mutation. Immunity 2001, 14:45-55.

18. Postic C, Shiota M, Niswender KD, Jetton TL, Chen Y, Moates JM, et al: Dual roles for glucokinase in glucose homeostasis as determined by liver and pancreatic beta cell-specific gene knock-outs using Cre recombinase. J Biol Chem 1999, 274:305-315.

19. Soriano P: Generalized lacZ expression with the ROSA26 Cre reporter strain. Nat Genet 1999, 21:70-71.

20. Higgins $\mathrm{GM}$, Anderson RM: Restoration of the liver of the white rat following partial removal. Arch Path Lab Med 1931, 12:916-922.

21. de Alboran IM, Baena E, Martinez A: c-Myc-deficient B lymphocytes are resistant to spontaneous and induced cell death. Cell Death Differ 2004, 11:61-68.

22. Le Y, Sauer B: Conditional gene knockout using Cre recombinase. Mol Biotechnol 2001, 17:269-275.

23. Davis AC, Wims M, Spotts GD, Hann SR, Bradley A: A null c-myc mutation causes lethality before 10.5 days of gestation in homozygotes and reduced fertility in heterozygous female mice. Genes Dev 1993, 7:671.

24. Postic C, Magnuson MA: DNA excision in liver by an albumin-Cre transgene occurs progressively with age. Genesis 2000, 26:149-150

25. Riu E, Ferre T, Mas A, Hidalgo A, Franckhauser S, Bosch F: Overexpression of c-myc in diabetic mice restores altered expression of the 
transcription factor genes that regulate liver metabolism. Biochem J 2002, 368:931-937.

26. Anand P, Gruppuso PA: Rapamycin inhibits liver growth during refeeding in rats via control of ribosomal protein translation but not capdependent translation initiation. J Nutr 2006, 136:27-33.

27. Thompson MD, Monga SP: WNT/beta-catenin signaling in liver health and disease. Hepatology 2007, 45:1298-1305.

28. He TC, Sparks AB, Rago C, Hermeking H, Zawel L, da Costa LT, et al: Identification of c-MYC as a target of the APC pathway. Science 1998, 281:1509-1512.

29. Mayhew CN, Bosco EE, Fox SR, Okaya T, Tarapore P, Schwemberger SJ, et al: Liver-specific pRB loss results in ectopic cell cycle entry and aberrant ploidy. Cancer Res 2005, 65:4568-4577.

30. Romero-Gallo J, Sozmen EG, Chytil A, Russell WE, Whitehead R, Parks WT, et al: Inactivation of TGF-beta signaling in hepatocytes results in an increased proliferative response after partial hepatectomy. Oncogene 2005, 24:3028-3041.

31. Michael MD, Kulkarni RN, Postic C, Previs SF, Shulman Gl, Magnuson MA, et al: Loss of insulin signaling in hepatocytes leads to severe insulin resistance and progressive hepatic dysfunction. Mol Cell 2000, 6:87-97.

32. Schulz TJ, Glaubitz M, Kuhlow D, Thierbach R, Birringer M, Steinberg P, et al: Variable expression of Cre recombinase transgenes precludes reliable prediction of tissue-specific gene disruption by tail-biopsy genotyping. PLoS One 2007, 2:e1013.

33. Garrick D, Sutherland H, Robertson G, Whitelaw E: Variegated expression of a globin transgene correlates with chromatin accessibility but not methylation status. Nucleic Acids Res 1996, 24:4902-4909.

34. Dobie KW, Lee M, Fantes JA, Graham E, Clark AJ, Springbett A, et al: Variegated transgene expression in mouse mammary gland is determined by the transgene integration locus. Proc Natl Acad Sci USA 1996, 93:6659-6664.

35. Robertson G, Garrick D, Wilson M, Martin DI, Whitelaw E: Age-dependent silencing of globin transgenes in the mouse. Nucleic Acids Res 1996, 24:1465-1471.

36. Baena E, Gandarillas A, Vallespinos M, Zanet J, Bachs O, Redondo C, et al: CMyc regulates cell size and ploidy but is not essential for postnatal proliferation in liver. Proc Natl Acad Sci USA 2005, 102:7286-7291.

37. Li F, Xiang Y, Potter J, Dinavahi R, Dang CV, Lee LA: Conditional deletion of c-myc does not impair liver regeneration. Cancer Res 2006, 66:5608-5612.

38. Zanet J, Pibre S, Jacquet C, Ramirez A, de Alboran IM, Gandarillas A: Endogenous Myc controls mammalian epidermal cell size, hyperproliferation, endoreplication and stem cell amplification. J Cell Sci 2005, 118:1693-1704.

39. Murphy DJ, Junttila MR, Pouyet L, Karnezis A, Shchors K, Bui DA, et al: Distinct thresholds govern Myc's biological output in vivo. Cancer Cell 2008, 14:447-457.

40. Schlaeger C, Longerich T, Schiller C, Bewerunge P, Mehrabi A, Toedt G, et al: Etiology-dependent molecular mechanisms in human hepatocarcinogenesis. Hepatology 2008, 47:511-520.

41. Feitelson MA: c-myc overexpression in hepatocarcinogenesis. Hum Pathol 2004, 35:1299-1302.

42. Calvisi DF, Thorgeirsson SS: Molecular mechanisms of hepatocarcinogenesis in transgenic mouse models of liver cancer. Toxicol Pathol 2005, 33:181-184.

43. Cavin LG, Wang F, Factor VM, Kaur S, Venkatraman M, Thorgeirsson SS, et al: Transforming growth factor-alpha inhibits the intrinsic pathway of cMyc-induced apoptosis through activation of nuclear factor-kappaB in murine hepatocellular carcinomas. Mol Cancer Res 2005, 3:403-412.

44. Valera A, Pujol A, Gregori X, Riu E, Visa J, Bosch F: Evidence from transgenic mice that myc regulates hepatic glycolysis. FASEB J 1995, 9:1067-1078.

45. He C, Hu H, Braren R, Fong SY, Trumpp A, Carlson TR, et al: c-myc in the hematopoietic lineage is crucial for its angiogenic function in the mouse embryo. Development 2008, 135:2467-2477.

46. Bettess MD, Dubois N, Murphy MJ, Dubey C, Roger C, Robine S, et al: c-Myc is required for the formation of intestinal crypts but dispensable for homeostasis of the adult intestinal epithelium. Mol Cell Biol 2005, 25:7868-7878. doi:10.1186/1472-6793-12-1

Cite this article as: Sanders et al:: Postnatal liver growth and regeneration are independent of $c$-myc in a mouse model of conditional hepatic c-myc deletion. BMC Physiology 2012 12:1.

\section{Submit your next manuscript to BioMed Central and take full advantage of:}

- Convenient online submission

- Thorough peer review

- No space constraints or color figure charges

- Immediate publication on acceptance

- Inclusion in PubMed, CAS, Scopus and Google Scholar

- Research which is freely available for redistribution

Submit your manuscript at www.biomedcentral.com/submit
C Biomed Central 